\title{
The Pattern of Joko Widodo's Political Dynasty Practices
}

\author{
Novia Fatimatuzzahra ${ }^{1 *}$, Dian Suluh Kusuma Dewi ${ }^{2}$ \\ 12 Department of Government Studies, Faculty of Social and Political Sciences, Universitas \\ Muhammadiyah Ponorogo \\ Jl. Jenderal Sudirman 65 B Tempel Turi, Jetis, Ponorogo, East Java, Indonesia, 63471
}

*Corresponding author: noviazahra45@gmail.com

\begin{abstract}
The political steps of President Joko Widodo's son (Gibran) and son-in-law (Bobby Nasution) have become the spotlight and a warm conversation in almost all levels of Indonesian society, especially in online media. This candidacy received many public responses because it was considered an excellent fit to take advantage of their father, Joko Widodo, which led to dynastic politics during the presidency. This research aims to discuss how the media discusses the patterns of political dynasties in Indonesia, especially in the era of Joko Widodo's leadership. Specifically, the purpose of this study is to determine the nomination of Gibran and Bobby, who are suspected of being a political dynasty through online media. This research uses a qualitative approach. Data collected through data mining is carried out with the NVIVO 12 Plus NCapture feature from local and foreign online news portals. The data is processed using NVIVO 12 Plus using manual coding with a qualitative approach and crosstabulation method. This research indicates Jokowi's involvement in using his capacity as president in Gibran and Bobby's nomination in the 2020 Regional Election. The controversy that has arisen shows the public's negative perception of political dynasties.
\end{abstract}

Article Info:

\section{INTRODUCTION}

After the New Order regime ended in 1998, democracy was buzzing everywhere (Sutisna, 2017). Democracy is believed to be the most appropriate way to achieve justice and freedom in society. There are three aspects to democratization. First, the greater the community's opportunity to make decisions; second, the scope (scope) is getting wider; third, the community has control over government administration involving capable actors.

In a democracy, elections are an element that public opportunities and opportunities in government can be opened. A country that adopts a democratic form of 
government should open the broadest possible political opportunity to ensure that the people participate actively in the government process. However, it cannot be denied that elections also open up opportunities for power domination by a handful of elites. 'Defense' which already has 'name' and 'reputation' capital, will be easier to get public attention. What then is not difficult to get relatives or family into essential positions in the government. Itis the biggest concern where the representation of democracy will be tainted by political dynasties (Susanti, 2017).

An example of one of the cases of political dynasties that have been hotly discussed and highlighted in Indonesia is Ratu Atut Chosiyah, the Governor of Banten. The dominance of the Atut clan has been widely discussed throughout Banten. Ratu Atut dynasty was formed since he was appointed as Acting Governor of Banten Djoko Munandar after previously serving as Deputy Governor of Banten in 2005. It was starting with the election of Tb Haerul Jaman, Atut's half-brother who ran as Deputy Mayor of Serang and ended winning in 2008. Then his younger sibling Ratu Atut, namely Ratu Tatu Chasanah, was elected as Deputy Regent of Serang 2010-2015. Furthermore, Airin is Ratu Atut's brother-in-law who became the Mayor of South Tangerang for the 2011-2015 period. Still not finished, Atut's stepmother, Heryani, was the Deputy Regent of Pandeglang Regency in 2011-2016.

Apart from the Ratu Atut dynasty, Gibran Rakabuming Raka's advancement in the Solo election and Bobby Nasution in the Medan election when their position as the President's son and son-in-law were being discussed. The community considered Bobby and Gibran 'ajimumpung' (taking advantage of the situation for personal gain) and used their father's position to get recommendations from the center. Apart from that, the community is also concerned about leading the region. Previously, they were deemed not to have the ability and sufficient political footprint, so that the public only considered them to take advantage of the political momentum by completing the President's reputation and position.

Furthermore, according to (Mukti \& Rodiyah, 2020), The practice of political dynasties in real democracy does not exist. In the constitution, every citizen's rights are guaranteed and upheld to vote and be elected. The Indonesian state belongs to all its citizens, not dominated by certain groups or families. Every citizen has the right to sit in the government seat as long as the requirements fulfilled and legally voted. That should be the practice of democracy that is clean and without distraction from interested parties. However, political dynasties in Indonesia are more visible as a culture.

The political dynasty then became a criticism of the statement that democracy was the solution to the monarchy and oligarchy system. The monarchy system is to pass power to families and heirs, while the oligarchy is a power that is only exercised by certain elites or groups (Suryatwan, 2020). So, if a country has practices of political dynasties and oligarchies that are increasingly transparent, this indicates that democracy has not yet reached a point of success. In many democratic countries, the emergence of political dynasties has been around for a long time. It raises concerns that there is an imbalance in the distribution of political power to show flaws in democratic representation in politics, called power breeds.

According to (Hargens, 2020) the essence of oligarchy lies not in its structure but by certain groups' power and authority. Oligarchy tends to a "cartel" work pattern to

\footnotetext{
2| Journal of Local Government Issues (LOGOS), 4 (1), March 2021, pp 1- 12 ISSN : 2620-8091 print | 2620-3812 online
} 
control the decision-making process in government. In a modern democracy, there has been a shift in the meaning of oligarchy itself. What started as a system used to control the government. Now, it is a flexible strategy to maintain power.

In previous research, according to (Hargens, 2020), the characteristics of the oligarchy are divided into several parts; the first is the government-controlled by several people. The first characteristic a basic understanding of the oligarchy itself. In terms of policy-making and decision-making, a handful of people from certain groups control the government, usually the political parties that win the election.

Second, Avoiding Public Participation. In a democracy, the general public is a significant part of the policy-making process. Without community involvement, real democracy is considered to have failed in defining the goal of democracy itself, namely, to serve the community. Unfortunately, this discussion about the general public's involvement in the policy-making process failed to occur under the oligarchic tradition.

Third, Resistant to Dispersion and Equity. The principle of equity causes prolonged conflict within the elite between those who have more merit and otherwise. However, the oligarchy adheres to the law of the proportional distribution of profits. Lastly, the oligarchy Exploiting Economic Gaps. Oligarchy can live in any form of the political system as long as there is an economic gap or inequality towards access to potential resources. This oligarchy does not only grow in 'finished' governments. However, oligarchy is also present in the political process before the formation of a government.

The political process is undoubtedly colored by various dynamics, from choosing state officials to become leaders and occupy the next seat of government to the dynamics of running the government. In this case, political parties are the leading players, so that the dynamic that is often of concern is the role of political parties in the process of gaining power, starting from forming coalitions to determining candidates. Before political contests began, candidates' appointment by political parties in regional elections (Pilkada) or elections was always an important topic of discussion, especially dynastic politics. Candidates came from the families of political party figures or government elites. Admittedly or not, dynastic politics within political parties thrive in the world of Indonesian politics.

Within the body of political parties in Indonesia, it must be admitted that an oligarchy can affect the mechanism for selecting candidates so that this process does not work as it should. The nomination of candidates by political parties is often based on elites and political party officials' orders, not on the candidate's quality, capability, and integrity. Political dynasties strengthen networks of power from the regional to the central level, with the primary objective of maintaining power in political parties and elite individuals and political officials themselves. Finally, political dynasties took over, and at the same time, spread democratic values in political parties (Gunanto, 2020).

The existence of a political dynasty, which is increasingly developing, has always been pros and cons. It is no longer common knowledge that political dynasties are assumed to have the potential to cause abuse of power. However, another option also develops the view that restrictions on the incumbent or the ruler's family and relatives

3| Journal of Local Government Issues (LOGOS), 4 (1), March 2021, pp 1- 12 ISSN : 2620-8091 print | 2620-3812 online 
from participating in the political scene can violate human rights and violate citizens' constitution.

The elite cycle in terms of changing leaders is one indicator that shows whether or not democracy is healthy in a country (Indarti, Herlina, Aminah, Apriani, \& Pranasari, 2020). If a country leader only dwells on one circle of family and kinship and an elite group, there will be leadership saturation because there will be a tendency for patterns in governing a country. The people's right to be elected will unconsciously begin to dissolve because familiar actors have dominated essential and strategic positions; if starting from the bottom, it will be difficult because there are no "insiders". The weakness of the democratic system in Indonesia has seen with the practice of Corruption and Nepotism (KKN).

Table 1. The President of the Republic of Indonesia's family who became an official.

\begin{tabular}{|c|c|c|c|c|}
\hline NO & PRESIDENT & YEAR & $\begin{array}{l}\text { FAMILIES WHO BECOME } \\
\text { PUBLIC OFFICIALS }\end{array}$ & KET \\
\hline 1 & Soekarno & $1945-1967$ & Megawati (5th President) & Child \\
\hline \multirow[t]{3}{*}{2.} & \multirow[t]{3}{*}{ Soeharto } & \multirow[t]{3}{*}{ 1967-1998 } & $\begin{array}{l}\text { MbakTutut (Minister of } \\
\text { Social Affairs 1998) }\end{array}$ & Child \\
\hline & & & $\begin{array}{l}\text { - TitiekSoeharto (Aleg DPR } \\
\text { RI 2014-2018) }\end{array}$ & Child \\
\hline & & & $\begin{array}{l}\text { - Tommy Soeharto (Aleg } \\
\text { DPR RI 1992-1998) }\end{array}$ & Child \\
\hline 3. & Habibie & 1998-1999 & - & - \\
\hline 4. & Gusdur & $1999-2001$ & $\begin{array}{l}\text { Yenni Wahid (Stafsus } \\
\text { President Gusdur) }\end{array}$ & Child \\
\hline \multirow[t]{2}{*}{5.} & \multirow[t]{2}{*}{ Megawati } & \multirow[t]{2}{*}{$2001-2004$} & $\begin{array}{l}\text { Puan Maharani (Chairman } \\
\text { of the Indonesian } \\
\text { Parliament 2019-2024) }\end{array}$ & Child \\
\hline & & & $\begin{array}{l}\text { Alm. TaufikKiemas (MRR } \\
\text { RI 2009-2014) }\end{array}$ & Husband \\
\hline 6. & SBY & $2004-2014$ & $\begin{array}{l}\text { EdhieBaskoro (Aleg DPR RI } \\
\text { 2014-Present) }\end{array}$ & Child \\
\hline 7. & Jokowi & 2014-Present & - & - \\
\hline
\end{tabular}

From the table above it can be seen that the President in Indonesia tends to relay power. Some also entered as politicians and added to the list of family politics, whether it is on a large scale, such as the son of a former president who later becomes president in the future or the son/partner of the president who occupies legislative seats and becomes a politician. The sons and daughters of President Soekarno besides Megawati, such as Rachmawati Soekarnoputri, Sukmawati Soekarnoputri, and Totok Suryawan Soekarnoputra who are still actively involved in politics.

4| Journal of Local Government Issues (LOGOS), 4 (1), March 2021, pp 1- 12 ISSN : 2620-8091 print | 2620-3812 online 
This article tries to look at the symptoms of the political dynasty pattern in the Jokowi administration. Besides, it tries to see how the media, both local and international, have the same perspective on this phenomenon.

Many researchers in Indonesia have carried out several studies on political dynasties. Political parties and regulations are the two main factors for continuing political dynasties in regional elections (Pilkada) (Susanti, 2017). Political parties have failed to carry out sustainable political regeneration (Djati, 2014). The usual model is the use of close and direct relatives such as in Kediri (Bimantara \& Harsasto, 2018) with a pattern of profiling and diaspora to legislative institutions such as in Banten (Sutisna, 2017), Bontang (Akbar \& Purnomo, 2019), Nagan Raya (Syahbandir, Hasan, \& Izwar, 2019) and strategic administrative positions in the Bureaucracy as happened in Riau (Darmansyah, Syahrani, \& Harirah, 2020). So it is not surprising if the findings (Prianto, 2016; Purwaningsih \& Widodo, 2020) of Political dynasties that create oligarchies in political parties in practice hinder good governance practice in the regions.

This article takes a different angle of analysis. First, placing the presidential family at the center of political dynasty studies had never been discussed before. Second, from a methodological perspective, this study records the pattern of Jokowi's political dynasty and public response from online media using the $\mathrm{N}$-Vivo feature.

\section{METHOD}

This research uses a qualitative approach. Qualitative research with research is analyzed through an inductive approach. The study used the method of Cross Tabulation Analysis. This analysis is a form of correlational analysis used to analyze the correlation between variables (Andespa, 2016) to make it easier to see a problem more deeply. The authors used a literature review to analyze content as data collection techniques. The discussion object takes the national issue, so the data is taken from literature such as online media, local and foreign media, journals, and legislation regarding regional elections, democracy, and political dynasties and dynastic politics. The data used in this research is an online news and then grouped into two news portal for foreign media and local media. The local media analyzed were from tirto.id (editions per October 2019December 2020), CNN Indonesia (10 December 2020), Sindo News (10 December 2020), and VOA Indonesia (16 December 2020). The Bloomberg news portals (8 December 2020) and NIKKEI Asia (8 December 2020) are used for foreign news. The data were taken from the period December 2019-December 2020 to ensure that the data arestill relevant to this issue of Jokowi's political dynasty.

Then, the data were collected using NVIVO 12 Plus with the NCapture technique, and then the coding was done manually. Manual coding using NVIVO 12 Plus is done by opening and reading the data that has been captured from the previous online news portal. Then content relevant to the topic will be coded on the nodes.

This research's object is the practice pattern of political dynasties during the leadership era of President Joko Widodo. This research is limited to only covering political dynasties to President Joko Widodo and also touches a little about the oligarchy in the government elite or political party bodies.

5| Journal of Local Government Issues (LOGOS), 4 (1), March 2021, pp 1- 12 ISSN : 2620-8091 print | 2620-3812 online 
Table 2. Research Variables and Indicators

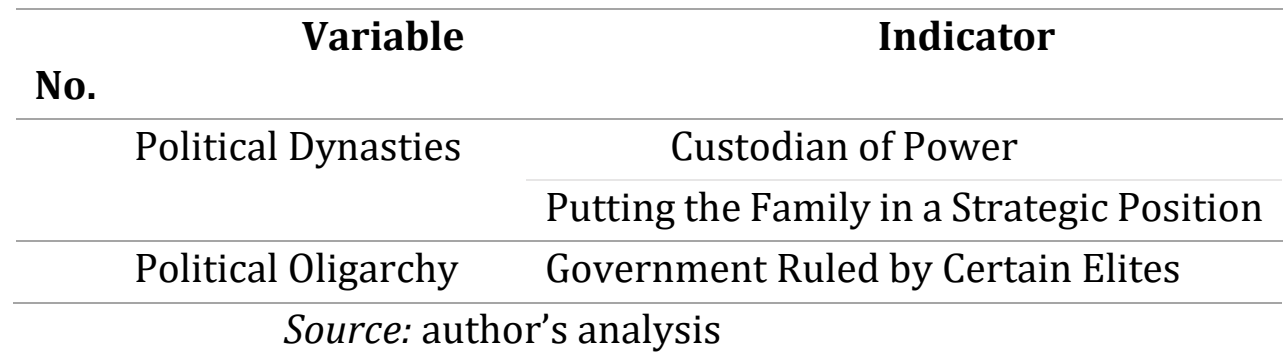

The table above is the variables and indicators that will be discussed in this study.

\section{RESULTS AND DISCUSSION}

\section{Political Dynasties: Maintaining Power and Putting Families in Strategic Positions}

The election of President Joko Widodo (Jokowi) for two terms from 2014-2019 to 2019-now cannot be separated from the support of the Indonesian Democratic Party (PDI-P). The same thing happened to Gibran Rakabuming and Bobby Nasution in starting their political careers by running for mayor of Solo and Mayor of Medan in the 2020 Election yesterday (Suryatwan, 2020). This time, Gibran and Bobby's advancement into the political scene surprised many parties. In an interview, Gibran said that he would not enter the world of politics shortly, although it is possible in the future. Itis also reinforced by Jokowi's branding, a leader from outside the political elite. The public then believed that Jokowi would not pass his power to his children. Now, what is happening is the antithesis of Jokowi's previous statement. Their son and son-in-law, Gibran and Bobby, departed from the same party as the party that supported Jokowi and succeeded in becoming President for two terms. Besides, Gibran also decided to start everything in Solo, a place where Jokowi became a famous mayor even throughout the world. Privilege as the President's son and son-in-law made it easier for them to walk freely. After Gibran and Bobby committed to running for the 2020 regional elections (Pilkada), Joko Widodo began to "make sure" to guard his children's success and son-in-law (Fealy, 2020). As quoted by Yoes C. Kenawas (VOA, 2020). Political dynasties overthrow the party's existing political regeneration. For example, a party cadre or deputy regent and mayor, who has been loyal to the party for ten years, must be eliminated by someone who has only been a party member for one year or a few months because a new candidate will be proposed and has blood ties or kinship with the elite or defense.

Previously, Gibran received a direct nomination recommendation from the chairman of the Indonesian Democratic Party (PDI-P), Megawati Soekarnoputri. This recommendation even defeated the previous potential PDI-P cadre, Achmad Purnomo (Bloomberg, 2020). This recommendation letter shows that Gibran, who has minimal experience in politics and parties, is privileged by the President's son's name. It illustrates that political dynasties have been systematically built within the PDI-P. Apart from that, political oligarchy is also perpetuated. Itis the first finding of the data in this study.

Admittedly or not, political dynasties cannot be separated from political actors' role to facilitate the path to specific goals. Before that, political parties also played an essential role in the formation of this political dynasty. There is no limit to kinship politics' participation in the recruitment process for political candidates (Muksin,

6| Journal of Local Government Issues (LOGOS), 4 (1), March 2021, pp 1- 12 ISSN : 2620-8091 print | 2620-3812 online 
Purwaningsih, \& Nurmandi, 2019). In addition to political parties, political actors emerge in which these actors are assumed to be party leaders can control political party policies, one of which is the policy on candidate recruitment itself (Shibghotulloh, Al-Banjari, \& Djuyandi). In today's theme, Megawati is an actor in the formation of political dynasties. As chairman of the PDI-P, Megawati recommended Gibran's nomination to run as a candidate in the Solo elections.

Not only Jokowi. For a long time, several presidents in Indonesia have tended to relay power. For example, President Soekarno (1945-19670), who later his daughter, Megawati Soekarnoputri, served as the 5th President of the Republic of Indonesia in 2001-2004. Former President Soeharto 1967-1998, whose children occupied government positions; Tutut (Minister of Social Affairs 1998) Titiek Soeharto (Member of The House of Representative of Republic of Indonesia (DPR RI) 2014-2018), Tommy Soeharto (Member of DPR 1992-1998). Megawati (2001-2004), whose child and the husband was involved in government; Puan Maharani (Chairman of the 2019-2024 DPR RI), Taufik Kiemas (Chairman of the People's Consultative Assembly (MPR) 1999-2014). Furthermore, Susilo Bambang Yudhoyono (2004-2014), Edhie Baskoro (Member of DPR 2014-Present) and some who have entered the world of politics as politicians and added to the list of family politics, whether it is on a large scale, such as the son of a former president who later becomes president in the future or the son/partner of the president who occupies legislative seats and becomes a politician. The sons and daughters of President Soekarno besides Megawati, Rachmawati Soekarnoputri, Sukmawati Soekarnoputri, and Totok Suryawan Soekarnoputra who are still actively involved in politics. Agus Harimurti Yudhoyono, son of Susilo Bambang Yudhoyono (SBY), ran for Governor of DKI Jakarta in 2017 but was not elected, adding to the long record of political dynasties and political oligarchs in Indonesia. It becomes an indication that Indonesia has been practicing "inheritance" of this position for a long time.

\section{Media Perspectives on the Nominations for Regional Heads of Gibran and Bobby}

From the picture below (Figure 1), it can be seen that the two variables of this study are Political Dynasty and Political Oligarchy from 8 news article sources processed by the author, both local and foreign media. From local media, they mostly talk about political oligarchy, where a particular elite/group runs the government with 51 relevant data from 6 online news articles. As quoted from the website (tirto.id, 2020a), in the first period of his leadership, Jokowi-Jusuf Kala (JK) announced a Work Cabinet in 2014 with a composition of "politics of reciprocation". The Jokowi-JK campaign team get strategic positions in the government, like Amran Sulaiman, who became the Team Leader, succeeded in getting the position as Head of National Development Planning Agency (Bappenas) and Andi Wijayanto, the most-significant donor in Jokowi-JK's candidacy to be Minister of Agriculture. Furthermore, the party that carries Jokowi in the 2014 presidential election won four ministerial seats. This data shows that Gibran and Bobby's nomination as Regional Head candidates is not the first oligarchic practice of the Jokowi period; this has happened since the first Jokowi-JK term.

7| Journal of Local Government Issues (LOGOS), 4 (1), March 2021, pp 1- 12 ISSN : 2620-8091 print | 2620-3812 online 


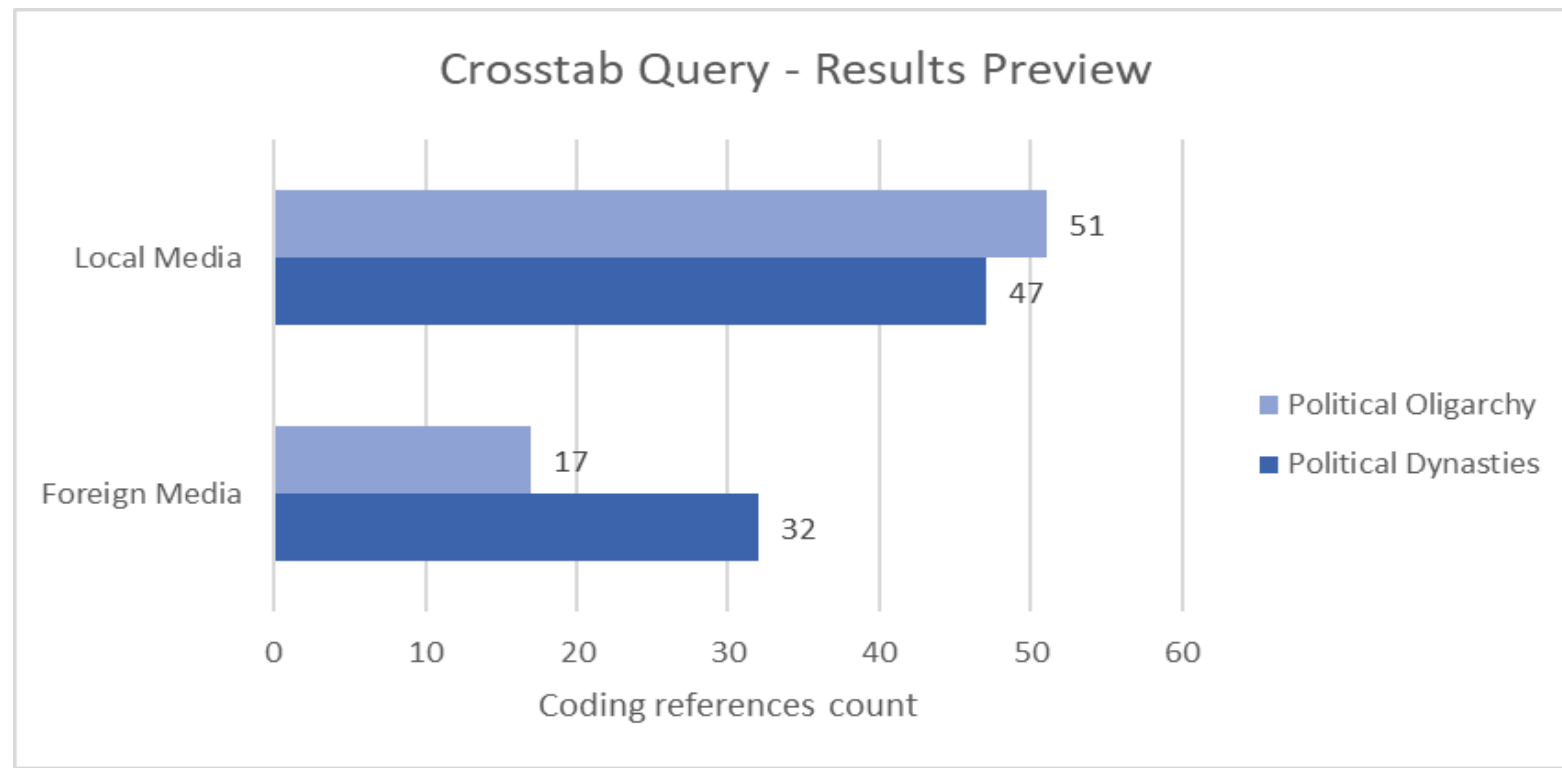

Figure 1. Authors' NVIVO Data Processing Results

Gibran's maneuvering towards the Chairman of the PDI-P, Megawati Sukarnoputri, is also a clear example of an oligarchy and is considered a privilege for Gibran as the son of the President (tirto.id, 2020b). It is doubtful if there are 'ordinary people' who are determined to meet the party chairman to recommend for nomination.

Moreover, with a small difference, 47 data are relevant to the variable, namely Political Dynasty (see Figure 1). This topic remains a hot topic of conversation, especially in the lead up to the 2020 regional elections and after Gibran's candidacy in the Solo and Bobby elections in the Medan regional elections. An interesting statement is quoted from (CNN, 2020) that Bobby and Gibran's victory has been predicted since the candidacy. Due to the President's children/relatives' advancement, it will be difficult to beat other candidates. It is like an unwritten rule in society's social structure that whoever runs for government officials from the President's relatives, especially if this is the President's son and son-in-law, the chances of winning will be even greater.

There is also an exciting statement where Gibran and Bobby's victory has further complemented and fulfilled Jokowi's political dynasty. Gibran and Bobby are businessmen by becoming politicians who automatically bring together power with capitalists (SINDONEWS.com, 2020). Reconciling power with capitalists is the main asset for a person to influence society and government fully. Power without a capitalist means that it must be prepared to become a "puppet" of the capital owners. Meanwhile, capitalists without power cannot fully control the market, which Gibran and Bobby have these two 'main' components.

Furthermore, for foreign media, the difference between the discussion of political dynasties and political oligarchs is quite far. With 32 relevant data, political dynasties are more frequently reviewed (Asia, 2020). The two nominations (re: Gibran and Bobby) mark how far Jokowi has gone from being a nobody to a political elite over the past six years. Jokowi is denial that this nomination means establishing a new political dynasty is invalid because having children and sons-in-law who are active in politics and holding an 
important position will have a long-term influence on his power Jokowi prepares to retire at the end of his second term in 2024.

In the article (Diplomat, 2020) it is explained that since the beginning of Indonesia's independence, it has indeed repeated the cycle in which the children of every President and Former President have essentialpositions in government.

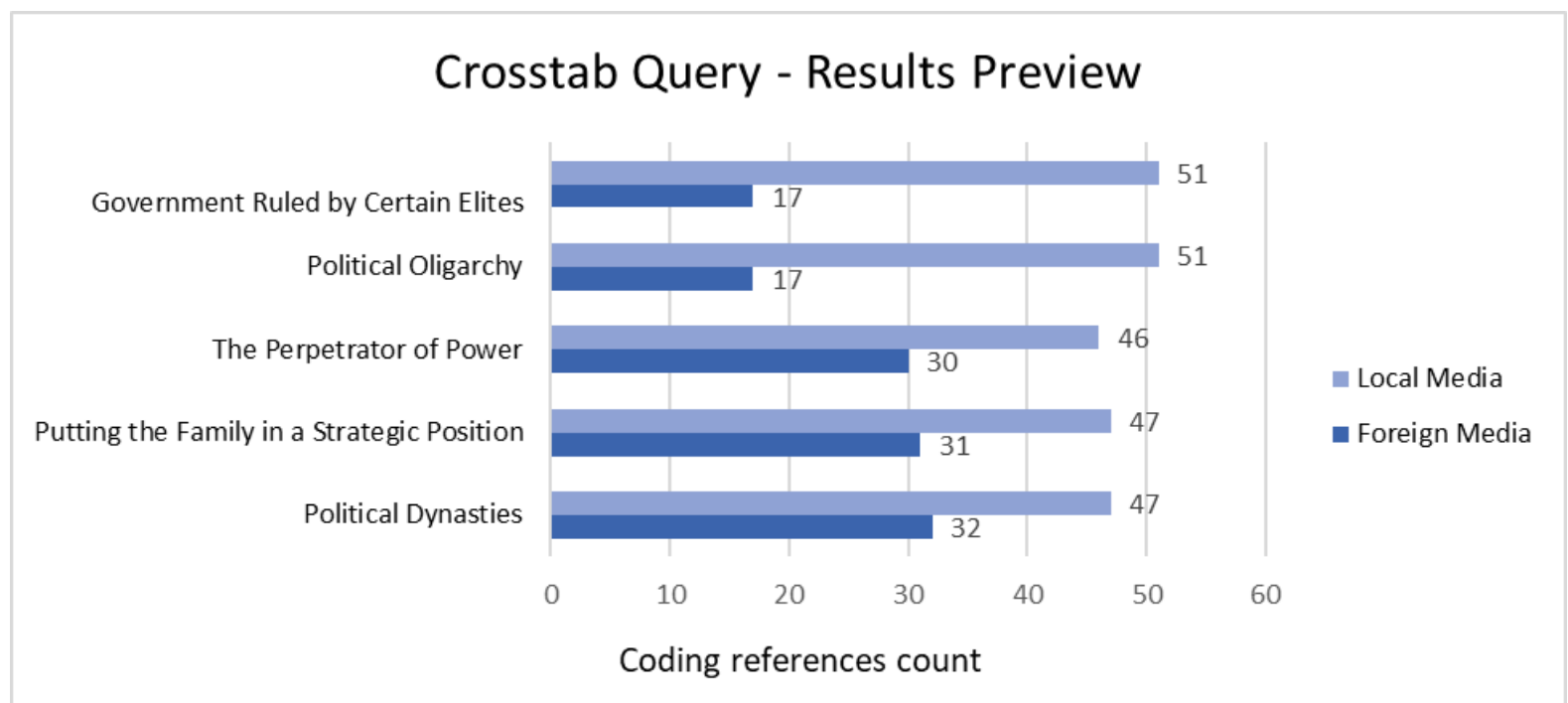

Figure 2. Results of Authors' NVIVO Data Processing

After the previous graphic image (figure 2) shows the two research variables and the frequency of relevant topics in the analyzed data, the image above shows the frequency of appearance of relevant data but is grouped in a broader scope as variables and indicators.

The variables and indicators in this study, whose data are taken from several news portals, are sufficient to show how Joko Widodo's political dynasty's practices occurred. "Government controlled by certain elites" can be analyzed through Gibran's maneuvers directly to Megawati Soekarnoputri, the Chair of the PDI-P, to get "advice" (tirto.id, 2020b).

"Putting Families in Strategic Positions "Jokowi himself did not directly assign or demote positions to his son and son-in-law. The election process for Gibran and Bobby also went through the correct procedure, namely the regional elections (Pilkada) (Fitriyah, 2018). However, what needs to be underlined here is that the elections were held during the COVID-19 pandemic with positive case reports that never fell from 1000 cases, and the total positive reports of COVID-19 as of 9 December 2020 were 592,900 cases (Liputan6, 2020). Minister of Political, Legal, and Security Affairs, Mahfud MD stated that it is still safe to carry out regional elections in this pandemic as long as it is under health protocols. However, epidemiologists fear that the regional elections will exacerbate the pandemic and increase daily cases of COVID-19 (BBCNews, 2020).

From the narrative above, it can be seen that the political ambitions of this 'elite' are no longer contained. The pandemic atmosphere that should be focused on 'recovery' is instead divided into less essential priority. The funds disbursed for regional elections and health procedures during voting can be diverted to facilitate health workers and 
provide affected communities (Fealy, 2020). However, the opposite happened. Jokowi prepared a safe way for his son to step into the political scene to preserve power.

For "perpetuating power", Jokowi prepares smart steps by securing the position of his son and son-in-law as Regional Heads and having provisions if later he wants to run for Presidency when Jokowi has stepped down from the presidency so that his power will not be cut off (Asia, 2020).

The theory (Mukti \& Rodiyah, 2020) states that political dynasties are a tradition in Indonesia and can be proven with the historical record of the previous president who secured his descendants' power position before retirement (Suryatwan, 2020) Jokowi also did the same. Not only that, but the practice of oligarchy in Indonesia is very transparent, and there is no longer any impression of being covered up. Privilege is evident in the world of politics in Indonesia. Roughly speaking, to serve as a public official must have two things; "Money" and "insiders".

The process of nominating Gibran and Bobby in the Solo and Medan Election was legally correct. However, this violates political ethics, where public officials' close family should not use their power to get a seat in government (CNN, 2020). Political dynasties also block the wider community's opportunity to nominate themselves as leaders, diminishing the value of democracy itself (Fitriyah, 2018).

\section{CONCLUSION}

Political dynasty is an indicator of the decline and weakness of the democratic system in a country. Unfortunately, Indonesia has "practiced" the tradition of inheriting this position for a long time. Furthermore, most of these impacts are felt by the community. Apart from the reduced opportunity to run for leadership, political dynasties are also prone to be infiltrated by corruption, which is easier to do because of backing everywhere. Again, these are the people who are at a disadvantage. Therefore, although it is not clearly "wrong" in the law, political dynasties are unethical things carried out by government officials.

The advancement of Gibran Rakabuming Raka and Bobby Nasution in the 2020 Regional Election became a conversation because they ran for regional heads to be President Joko Widodo's son and son-in-law, which indirectly was one of the practices of the political dynasty in the era of Joko Widodo administration. Gibran and Bobby's minimal political track record is increasingly becoming the butt of the community because it is considered that they will not be able to win the 2020 regional elections (Pilkada) if not as the President's son and son-in-law.

The political dynasty in the Jokowi period reinforces the narrative that political dynasties and oligarchs are traditions that have been passed down from generation to generation since the first President of Indonesia, Soekarno, until he passed down to subsequent Indonesian Presidents. The democracy in Indonesia cannot be carried out with the true meaning of democracy itself because political dynasties have injured it.

\section{REFERENCES}

Akbar, P., \& Purnomo, E. P. (2019). Model Dinasti Politik Di Kota Bontang. JWP (Jurnal Wacana Politik), 4(2), 145-156. https://doi.org/10.24198/jwp.v4i2.25381

10| Journal of Local Government Issues (LOGOS), 4 (1), March 2021, pp 1- 12 ISSN : 2620-8091 print | 2620-3812 online 
Andespa, R. (2016). Strategi Industri Perbankan di Sumatera Barat: Pemilihan Segmentasi Pasar untuk Menciptakan Pelayanan yang Memuaskan. Maqdis: Jurnal Kajian Ekonomi Islam, 1(1), 47-62. http://dx.doi.org/10.15548/maqdis.v1i1.15

Asia, N. (2020). Indonesia's Jokowi turns politics into a family business, https://asia.nikkei.com/Opinion/Indonesia-s-Jokowi-turns-politics-into-afamily-business

BBCNews. (2020). Pilkada di tengah pandemi Covid-19, pakar tetap khawatirkan soal klaster baru, Mahfud klaim 'tidak terjadi apa-apa', https://www.bbc.com/indonesia/indonesia-55241402

Bimantara, N., \& Harsasto, P. (2018). Analisis Politik Dinasti di Kabupaten Kediri. Journal of Politic and Government Studies, 7(04), 201-210.

Bloomberg. (2020). Indonesia May Have a New Political Dynasty With Jokowi's Family, https://www.bloomberg.com/news/articles/2020-12-07/indonesia-may-havea-new-political-dynasty-with-jokowi-s-family?utm_source=url_link.

CNN. (2020). Kemenangan Gibran dan Bobby, Sejarah Baru Dinasti Jokowi, https://www.cnnindonesia.com/nasional/20201210094828-32-

580351/kemenangan-gibran-dan-bobby-sejarah-baru-dinasti-jokowi.

Darmansyah, R., Syahrani, S. D., \& Harirah, Z. (2020). Potret Dinasti Politik dalam Pengisian Jabatan Administratif. Journal of Political Issues, 2(1), 34-46. https://doi.org/10.33019/jpi.v2i1.28

Diplomat, T. (2020). Could Jokowi's Family Become Indonesia's Newest Political Dynasty?, https://thediplomat.com/2020/08/could-jokowis-family-becomeindonesias-newest-political-dynasty/

Djati, W. R. (2014). Revivalisme Kekuatan Familisme dalam Demokrasi: Dinasti Politik di Aras Lokal. Masyarakat: Jurnal Sosiologi, 203-231.

Fealy, G. (2020). Jokowi in the Covid-19 Era: Repressive Pluralism, Dynasticism and the Overbearing State. Bulletin of Indonesian Economic Studies, 56(3), 301-323. https://doi.org/10.1080/00074918.2020.1846482

Fitriyah, F. (2018). Politik Dinasti Pada Kandidasi Perempuan dalam Pilkada Serentak 2015 di Jawa Tengah. Jurnal Ilmu Sosial, 17(1), 39-52. https://doi.org/10.14710/jis.17.1.2018.39-52

Gunanto, D. (2020). Tinjauan Kritis Politik Dinasti di Indonesia. Sawala: Jurnal Administrasi Negara, 8(2), 177-191._https://doi.org/10.30656/sawala.v8i2.2844

Hargens, B. (2020). Oligarchic Cartelization in Post-Suharto Indonesia. Disertations:Walden

https://scholarworks.waldenu.edu/dissertations/7873

University.

Indarti, D. M., Herlina, M., Aminah, S., Apriani, T., \& Pranasari, M. A. (2020). The High Political Costs in Local Head Election (Case Study in Indonesia). European Journal of Molecular \& Clinical Medicine, 7(11), 653-682.

Liputan6. (2020). Update Corona Rabu 9 Desember 2020: 592.900 Positif Covid-19, Sembuh 487.445, Meninggal 18.171, https://www.liputan6.com/news/read/4429281/update-corona-rabu-9desember-2020-592900-positif-covid-19-sembuh-487445-meninggal-18171

Muksin, D., Purwaningsih, T., \& Nurmandi, A. (2019). Praktik Dinasti Politik Di Aras Lokal Pasca Reformasi: Studi Kasus Abdul Gani Kasuba Dan Ahmad Hidayat Mus Pada

11| Journal of Local Government Issues (LOGOS), 4 (1), March 2021, pp 1- 12 ISSN : 2620-8091 print | 2620-3812 online 
Pilkada Provinsi Maluku Utara. JWP (Jurnal Wacana Politik), 4(2), 133-144. https://doi.org/10.24198/jwp.v4i2.25336

Mukti, H. H., \& Rodiyah, R. (2020). Dynasty Politics in Indonesia: Tradition or Democracy? Journal of Law and Legal Reform, 1(3), 531-538. https://doi.org/10.15294/jllr.v1i3.38090

Prianto, B. (2016). Partai Politik, Fenomena Dinasti Politik dalam Pemilihan Kepala Daerah, dan Desentralisasi. Publisia: Jurnal Ilmu Administrasi Publik, 1(2), 105117. https://doi.org/10.26905/pjiap.v1i2.436

Purwaningsih, T., \& Widodo, B. E. C. (2020). The Interplay of Incumbency, Political Dynasty and Corruption in Indonesia: Are Political Dynasties the Cause of Corruption in Indonesia?. Revista UNISCI 18(53), 157-176. https://www.researchgate.net/deref/http\%3A\%2F\%2Fdx.doi.org\%2F10.31439 \%2FUNISCI-89

Shibghotulloh, D. A. M., Al-Banjari, H., \& Djuyandi, Y. (2020). Peran Aktor Dalam Proses Pembentukan Dinasti Politik (Studi Kasus Di Kabupaten Purwakarta). Paradigma Polistaat, 3 (1), 26-48. http://dx.doi.org/10.23969/paradigmapolistaat.v3i1.2931

SINDONEWS.com. (2020). Kemenangan Gibran dan Bobby Sempurnakan Dinasti Politik Jokowi, https://nasional.sindonews.com/read/263032/12/kemenangan-gibrandan-bobby-sempurnakan-dinasti-politik-jokowi-1607566351.

Suryatwan, A. (2020). Dinasti Politik Pada Kepemimpinan Presiden Jokowi Akibat Kontestasi Politik Lokal Gibran-Bobby. Journal Publicuho, 3(3), 289-300. http://dx.doi.org/10.35817/jpu.v3i3.12972

Susanti, M. H. (2017). Dinasti Politik dalam Pilkada di Indonesia. Journal of Government and Civil Society, 1(2), 111-119. http://dx.doi.org/10.31000/jgcs.v1i2.440

Sutisna, A. (2017). Gejala proliferasi dinasti politik di Banten era kepemimpinan gubernur Ratu Atut Chosiyah. Politik Indonesia: Indonesian Political Science Review, 2(2), 100-120. https://doi.org/10.15294/jpi.v2i2.9329

Syahbandir, M., Hasan, E., \& Izwar, I. (2019). A Political Dynasty in Nagan Raya District. Paper presented at the 1st Aceh Global Conference (AGC 2018). https://dx.doi.org/10.2991/agc-18.2019.38

tirto.id. (2020a). Di Bawah Jokowi, Oligarki Kian Mencengkeram \& Demokrasi Makin Semu, https://tirto.id/di-bawah-jokowi-oligarki-kian-mencengkeramdemokrasi-makin-semu-f7XT.

tirto.id. (2020b). Manuver Gibran Lobi Megawati: Cara Instan Demi Tiket Pilwalkot Solo, https://tirto.id/manuver-gibran-lobi-megawati-cara-instan-demi-tiketpilwalkot-solo-ekye.

VOA. (2020). Dinasti Politik: Karena Kesempatan Terlalu Sayang Dilewatkan, https://www.voaindonesia.com/a/dinasti-politik-karena-kesempatan-terlalusayang-dilewatkan/5701580.html. 